\title{
Urban planning and the everyday experience of Palestinian women in Jaffa
}

\author{
Hanaa Hamdan-Saliba \\ Universitat Autònoma de Barcelona. Departament de Geografia \\ Hanaben8@gmail.com
}

Received: October 2012

Accepted: May 2013

\begin{abstract}
This article aims to examine how planning policies and practices affect the everyday spatial practice of Palestinian women living in Jaffa. To do this, in-depth interviews were conducted with Palestinian women living in Jaffa, and afterward, "thematic analysis" method was used to analyze the narratives. The main finding of this study is that the ignoring, neglecting and discriminatory planning of the local and national institutions, has produced un-appropriate and un-safety spaces for Palestina women, which in turn lead to limit and reduce their everyday spatial practices and to exclude them to a limited social, cultural, economic and geographical space. At the same time, these discriminated and ignoring policies lead Palestinian women to create alternative-Palestinian spaces, which despite being limited and narrow, allow them to expand their spatial mobility, feel comfortable and re-define their identity.
\end{abstract}

Keywords: planning; power relations; Palestinian women; Jaffa; exclusion; alienation.

\section{Resum. Planificació urbana $i$ la experiència quotidiana de les dones palestines a Jaffa}

Aquest article pretén examinar com les polítiques de planificació afecten la pràctica espacial quotidiana de les dones palestines que viuen a Jaffa. Per fer-ho, s'han realitzat entrevistes en profunditat a dones palestines residents a Jaffa i a continuació s'ha utilitzat el mètode de "l'anàlisi temàtica» per analitzar les narratives. El principal resultat de l'estudi és que la planificació de les institucions locals i nacionals, que ignoren, ometen i discriminen les dones palestines, ha produït espais inadequats i insegurs. Aquests espais limiten i redueixen les seves pràctiques espacials quotidianes i exclouen les dones a uns espais socials, culturals, econòmics i geogràfics limitats. $\mathrm{Al}$ mateix temps, aquestes polítiques discriminatòries $\mathrm{i}$ indiferents condueixen les dones palestines a crear espais palestins alternatius que, malgrat ser limitats i petits, els permeten eixamplar la seva mobilitat espacial, experimentar confort i redefinir les seves identitats.

Paraules clau: planificació; relacions de poder; dones palestines; Jaffa; exclusió; alienació. 
Resumen. Planificación urbana y la experiencia cotidiana de las mujeres Palestinas en Jaffa

Este artículo pretende examinar cómo las políticas de planificación urbana afectan a la práctica espacial cotidiana de las mujeres palestinas que viven en Jaffa. Para ello se han realizado entrevistas en profundidad a mujeres Palestinas residentes en Jaffa y a continuación se ha utilizado el método de "análisis temático» para analizar las narrativas. El principal resultado del estudio es que la planificación de las instituciones locales y nacionales, que ignoran, omiten y discriminan a las mujeres palestinas, ha producido espacios inadecuados e inseguros. Estos espacios limitan y reducen sus prácticas espaciales cotidianas y reducen a las mujeres a unos espacios sociales, culturales, económicos y geográficos limitados. Al mismo tiempo, estas políticas discriminatorias e indiferentes conducen a las mujeres palestinas a crear espacios palestinos alternativos que, a pesar de ser limitados y pequeños, les permiten ampliar su movilidad espacial, experimentar confort y redefinir sus identidades.

Palabras clave: planificación; relaciones de poder; mujeres palestinas; Jaffa; exclusión; alienación.

Résumé. La planification urbaine et l'expérience quotidienne des fermmes palestiniennes à Jaffa

L'objectif de l'article est d'examiner comment les politiques de planification conditionnent la pratique spatiale quotidienne des femmes palestiniennes vivant à Jaffa. Pour ce faire, des entrevues en profondeur chez des femmes palestiniennes qui habitent à Jaffa ont été menées, et ensuite une "analyse thématique" a été utilisé afin d'analyser les narratives. Le résultat principal de l'étude est que la planification des institutions locales et régionales, qui ignorent, omettent et discriminent, a produit des espaces qui sont perçus par les femmes palestiniennes comme inappropriés et pas sûres. Cela a limité et réduit leurs espaces de quotidienneté et a exclu les femmes dans des espaces géographiques, économiques, sociaux et culturels limitées. Au même temps, ces politiques qui ignorent et discriminent ont mené les femmes palestiniennes à créer des espaces palestiniens alternatifs qui, malgré être limités et réduits, permettent élargir leur mobilité spatiale, se sentir à l'aise et redéfinir leur identité.

Mots clé: planification; relations de pouvoir; femmes palestiniennes; Jaffa; exclusion; aliénation.

\section{Summary}

Introduction Feeling of alienation as result

Spatial Planning as a tool of control Jaffa, the "bleached ghost town" Conceptual framework: Exclusion, alienation and belonging from/to different spaces as result of oppressive spatial planning policies

Spatial exclusion as result of ignoring planning policies of development and renewal

Belonging to Jaffa due to the injustices of spatial planning policies

Conclusion: creating alternative spaces

Bibliographical references 


\section{Introduction}

This article focuses on the daily spatial experience of Palestinian ${ }^{1}$ women living in Jaffa in the context of national power relations, and in particular it examines how planning policies and practices affect and shape the everyday spatial practices of these women living.

The Zionist project sees in the Palestinian city a danger for its existence; therefore, the war of destruction and erasure was declared on these cities. This war was expressed by planning policies and laws and urban renewal. Through them the dominant group, the Jewish succeed to control the land and oppressed the native Palestinian. On this basis, the planning institutions in Israel, in general, and in Tel Aviv-Jaffa, in particular, have developed discriminating and ignoring planning and spatial policies (Fenster, 2007; Monterescu, 2007; Yiftachel, 2006; LeVine, 1999). This article indicates that these discriminating and ignoring spatial planning policies and practices lead to un-appropriate, un-safety and alien spaces, which in turn exclude and reduce the Palestinian women geographical activities, into a contractile and limited space. At the same time, these policies and practices strengthen their sense of belonging to Jaffa which include their personal and collective memory and which they know and love. Also, those practices lead them to create alternative Palestinian space, although limited and narrow. Nevertheless, through it, they can expand their spatial mobility and in turn fulfil their right for using spaces, for belonging and memory.

The first part of this article will focus on the theoretical background and mainly on the issues of urban planning and gender. The second part will present a general background regarding the spatial changes which occurred in Jaffa in the aftermath of the 1948 events. Then, the article discusses the finding and the final part presents the conclusions.

\section{Spatial Planning as a tool of control}

The basic aim of the modern planning is to manage the disorder which is caused by the appearing of the "Other" in the urban space, such as women, minorities, ethnic groups, immigrants, and latter the homo-lesbian. Actually, the function of planning is to regulate the land use and to organize the activities of people. Regulation determines who can do what and where, and even when (Sandercock, 2003; Yiftachel, 1998; Sibley, 1995). Planning is a discipline based on scientific knowledge, which Foucault (1980) considered a modern power that brings new patterns and tools of control. Planning policies and laws are considered to be the main instruments, used by the dominant group, for controlling, preserving and reproducing its own spatial interests

1. This article refers to the Palestinian women who have Israel citizenship, living in the Palestinian territory which occupied in 1948, and which Arabic as mother tongue. The Palestinian population belongs to religions, Islam and Christianity. We refer to Jewish women who have Israel citizenship too. 
(Fenster, 2007; Madanipour, 2003; Sandercock, 2003; Yiftachel, 1998; Sibley, 1995). Accordingly, the urban space and the built environment express a hierarchy which is based on the historical concept of power relationships (Harvey, 1996; Lefebvre, 1991; Foucault, 1980). It represents and reflects the ideas and interests of those who plan and construct in the space, the dominant group. Of course, space is not the only expression of ideology, but it is central to the action and reproduction of ideology (Cresswell, 1996; Lefebvre, 1991; Mitchell, 2000).

Past colonial regimes used modern planning, and a series of spatial technologies to control space, to dispossess the indigenous and exclude them. For example, in United States and Canada, the native Indians were settled by force in reservations. In Australia the term of "terra nullius", meaning "not used land", was used, justifying the occupation of the land by the colonists (Sandercock, 2003; Jacobs, 1996). Spatial segregation and exclusion were used against natives and ethnic minorities, whose members were restricted to limited areas and became "invisible".

New theories, which are centred on the relations between space, marginal groups and power, have emphasized the need to recognize cultural and social differences and to take in account the demands of the different groups living in the urban space (Fenster, 2005; Sandercock, 2000, 2003; Fincher and Jacobs, 1998; Razack, 1998; Healley et al., 1997; Young, 1990; Hayden, 1995). These theories underline the own spatial experience of different groups while taking into consideration the voice of the "Other", providing a representation for these persons, being aware of their culture and needs.

According to these theories, dominant and modern planning ignores the features and the historical, social, cultural and spatial needs of minorities, natives, ethnic groups, and women. As a result, an excluded, separated, and discriminated space is created, which reflects the interests and the spatial narrative of the dominant group (Fincher and Jacobs, 1998; Ritzdorf, 1997; Marcuse, 1995). In addition, the planners, who belong to the dominant group, tell only one geographic and historical narrative and reproduce the memory of their group. In contrast, the story of marginalized groups, including natives and women, is absent from the urban space (Fenster, 2007; Sandercock, 2003; Zukin, 1995). Memory expresses spatial power, which helps people to define their past and therefore enables the individual to have contact with the built environment (Hayden, 1995; Zukin, 1995; Casey, 1987). Said (1999) argues that the significant struggle of the Palestinians is about their right for a remembered presence, and the related right to demand and acquire a collective historical reality.

The claim over space may also include the right to memory and belonging, which is structured and defined by the daily activities of individuals and social organizations (Fenster, 2007; Sandercock, 2003). Thus, the daily, repeated use of certain spaces in the city constructs and shapes the users' sense of belonging to it and fulfils their rights to use these places (Leach, 2002; de Certeau, 1984). Developing this argument, Sandercock (2003) contends that the strug- 
gle of different groups over the use of urban space creates a "good city" and expands the sense of belonging to the space. She argues that three elements determine the sense of belonging to the city; these are memory, desire and soul. Memory locates the individual in the wider historic framework - family, community, urban and national history. Therefore memory loss means to lose the personal and collective memory. In addition, Fenster (2005) argues that the spatial memory of a specific place, which is accumulated as a result of daily use and knowledge of the place, actually creates the feeling of belonging.

In the Israeli context, which this article regards as a colonial state, the planning was aggressively employed against the Palestinian native, to fulfil the aims of the national-Zionist project of control over land and judaization of the space (Hamdan-Saliba and Fenster, 2012; Yacobi, 2002; Yiftachel, 1998). Yiftachel (1998) argues that planning as a tool of control and oppression operated in four dimensions: Territorial Dimension, which is expressed by the patterns of control on land; Procedural Dimension which includes implementation procedures of master plans and planning policy; Social-Economic Dimension which maintained the socio-economic gap between the dominate and the marginal group; and the Cultural Dimension, which impacted on collective cultural identities in the city or country. He also describes the planning in Israel as part of the "ethnocracy" regime which helps to one ethnic-group to expand at the expense of a multi-ethnic territory, and mainly at the expense of indigenous Palestinians (Yiftachel, 2006).

In this way, the Palestinian native-minority, their spatial need, history and narrative were systemically excluded from the planning discourse and space design, while the Jewish spatial needs and narrative have been emphasized. According to Madanipour (2003) the national narrative provides legitimating for exclusion and to create hegemony, also provides a definition of "us", while separating "us" from the "other". Fenster (2007) argues that professional and institutional planning in Israel represents and implements the Zionist ideology, and thus necessarily is not able to represent the narrative and spatial memory of the Palestinians.

In a gender context, one of the main arguments of the feminists' discourse is that the design of the modern urban space was made by educated Western men, who belong to the dominant group, and therefore the space reflects their personal experience and the interests of their group (Fenster, 2005; Sandercock, 2003; Kild, 1999; Massey, 1994; Spain, 1993; Willson, 1991). This led to the creation of a space that serves the existing power relationships, which in our case is both national and gender power relationships, and then reproduces them. This space endangers women by inciting violence against them (Markus, 2002; Willson, 1995). Furthermore, the neglect and the lack of consideration for women's needs, strengthens the exclusion of women caused by the spatial separation between women and men. This situation greatly adds to the reduction of women's accessibility to public spaces; in other words, to the creation of "gendered spaces" (Martin and Sparke, 2003; Sandercock, 2003; Spain, 1993). The concept "gendered spaces" it is not just connected to the presence 
or absence of women in specific spaces, but it is also related to certain patterns of spatial use and behaviour, and to the meaning of power relationship. "Gendered spaces" is expressed by symbols which are used in specific spaces, by distorting the meaning of space, such as forbidden vs. permitted, public vs. private and spaces of "modesty and un-modesty" (Makdisi, 2005; Fenster, 2007; Massey, 1994).

It is important to mention here that the meaning of urban space is not universal for all women, but rather it is different in terms of class, ethnic and cultural group. Women who belong to the dominant group have been given far more recognition than women who belong to marginal groups (Willson, 1995, 1991).

In sum, modern planning does not consider the needs and the demands of different cultural-native and marginal groups, and ignore their spatial experiences and cultural needs. This ignoring leads to un-appropriate urban space, especially for women who belong to marginal group, and thus exclude them from the public space into limited spaces (Sandercock, 2000, 2003; Fincher and Jacobs, 1998; Razack, 1998; Healley et al., 1997; Hayden, 1995; Young, 1990).

\section{Jaffa, the "bleached ghost town"}

Palestinian urban spaces underwent drastic changes as a result of 1948 facts and the establishment of the State of Israel. Bishara (2008) describes this change as a "breakage", which caused the total destruction of Palestinian cities and halted their modernization process. The Zionist project believes that the Palestinian city is dangerous for its existence; therefore, war and destruction was declared on these cities. Accordingly and as a result of the "Nakba" (the Arabic word for "catastrophe") the Palestinian native population lost its economic, political and cultural elite, and was excluded to the urban margins. Before the founding of the State of Israel, the city of Jaffa was a socio-economic centre for Palestinians; but was subsequently emptied of all of its physical, social, cultural and historical content (Rothbard, 2005; Al-Bawab, 2003). Since 1948 it has become a poor, neglected and marginalized neighbourhood (map 1). ${ }^{2}$

From the end of the $19^{\text {th }}$ century until 1948, Jaffa was the most important Palestinian port city, known for its economic, social and cultural development. This growth was reflected in the spatial landscape, which included new Palestinian, Arabic, Jewish and European-style neighbourhoods: public buildings, consulates, cinemas, coffee-shops and restaurants, economic and commerce centres, banks, hotels, political parties and women's organizations (Rothbard, 2005; Al-Bawab, 2003).

2. In 1947 , the Palestinian population of Jaffa was approximately 70,800; of whom just 3,600 remained after 1948, while the remainder became refugees. Today the Palestinian population of Tel Aviv-Jaffa stands at approximately 16,200, which accounts for $4 \%$ of the total population with the majority (approximately 90\%) living in the South (Statistical Abstract of Tel-Aviv Jaffa, 2011, table no. 2.2 and 2.21) 


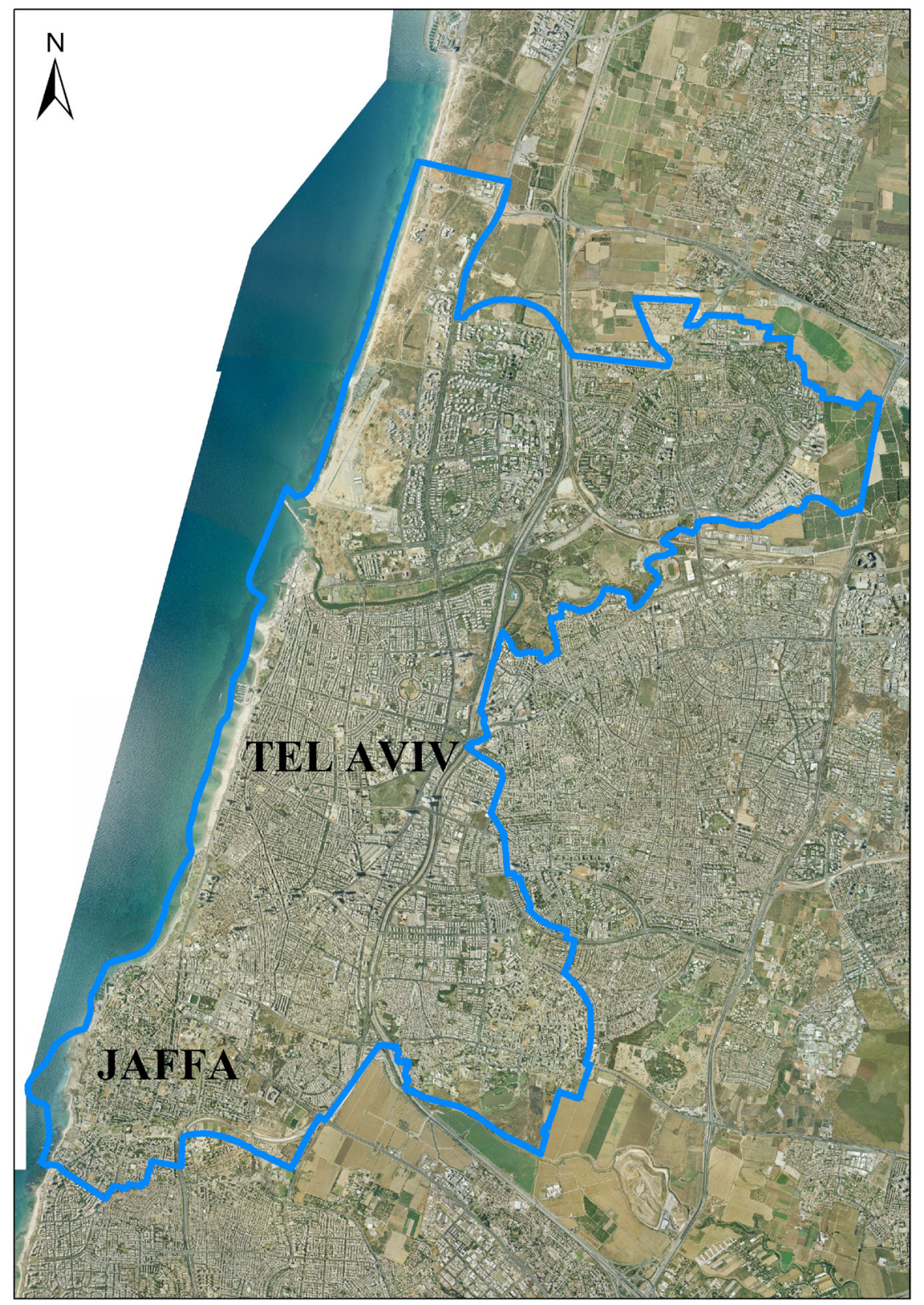

Map 1. Tel-Aviv Jaffa.

Source: Prepared by The Arab Center for Alternative Planning <http://www.ac-ap.org/>. 
However, today the pre-1948 Jaffa only exists in the collective memory of Palestinian residents, and refugees (Monterescu, 2007). The Palestinian sociologist Tamari (2000) describes the Jaffa of today as "a figment of the imagination. There is no parallel between the city of our parents and this bleached ghost town". Said (1999: 14) describes "[h] ow the history of ancient Palestine was gradually replaced by a largely fabricated image of ancient Israel..." and asserts that the geography of Palestine, as he knew it, no longer exists. The changes in Jaffa were described by Mazawy and Koury-Makhoul (1991: 36) as follows: "Since 1948 the fate of the city was to disappear progressively but consistently [...] a large part of the city was erased [...] the reconstruction of the old city, [...] all these projects have strategic and political defined purposes: basic changes of the spatial-cultural characteristic of the city."

The main objective of the planning policy in Jaffa mirrors the planning policy throughout Israel since its establishment; to have total control over the space and then to judaize it. Accordingly we can divide the planning policies and practices in Jaffa in four phases.

First phase: Initially in the aftermath of 1948 , the policy was characterized by emptying and destroying Palestinian areas in Jaffa. The remaining Palestinians, who would live under the military regime until 1950, ${ }^{3}$ were centred in Ajami neighbourhood, and their possessions, land and buildings were automatically transferred to the Custodian of Absentee Property, which were subsequently used to house the new Jewish immigrants (Monterescu, 2007). In the process of destruction and erasure, Mansheia neighbourhood was completely destroyed, while Ajami and Jabaliya neighbourhoods (map 2) were partially destroyed. Furthermore, $70 \%$ of the old city building was demolished and today the remains serve as an artists' colony and tourist centre (Monterescu, 2007; Rothbard, 2005). The physical destruction has also damaged the social and spatial characters of Jaffa. Fenster (2007: 193) argues that "the process of building the Jewish nation included not only social, cultural, economic and political building, but also the construction of the space as Jewish and the erasure of the Palestinian past". In this way the urban planning of Tel Aviv-Jaffa disregards the memory of the Palestinian and only the relatively new memory of the Jewish majority is expressed in the planning and design of the urban space (LeVine, 1999; Rothbard, 2005).

Second phase: Following the mass destruction of Jaffa, the city was neglected and poorly developed, which in turn prepared the area for the gentrification process and the entry of real estate capital. The municipality with the help of state-owned housing companies, "Amidar" and "Halmish", and the Israel Land Administration prevented the maintenance of the old city buildings of Jaffa and its public space.

Third phase: In the 1980's the planning policies started to change, from indifference and institutionalized neglect to planning and rehabilitation (Goldhaber, 2010; Monterescu, 2007). The outcome of these activities has been gentrification, which ultimately allows the municipality to continue with its

3. In 1950, Jaffa became part of Tel-Aviv. 


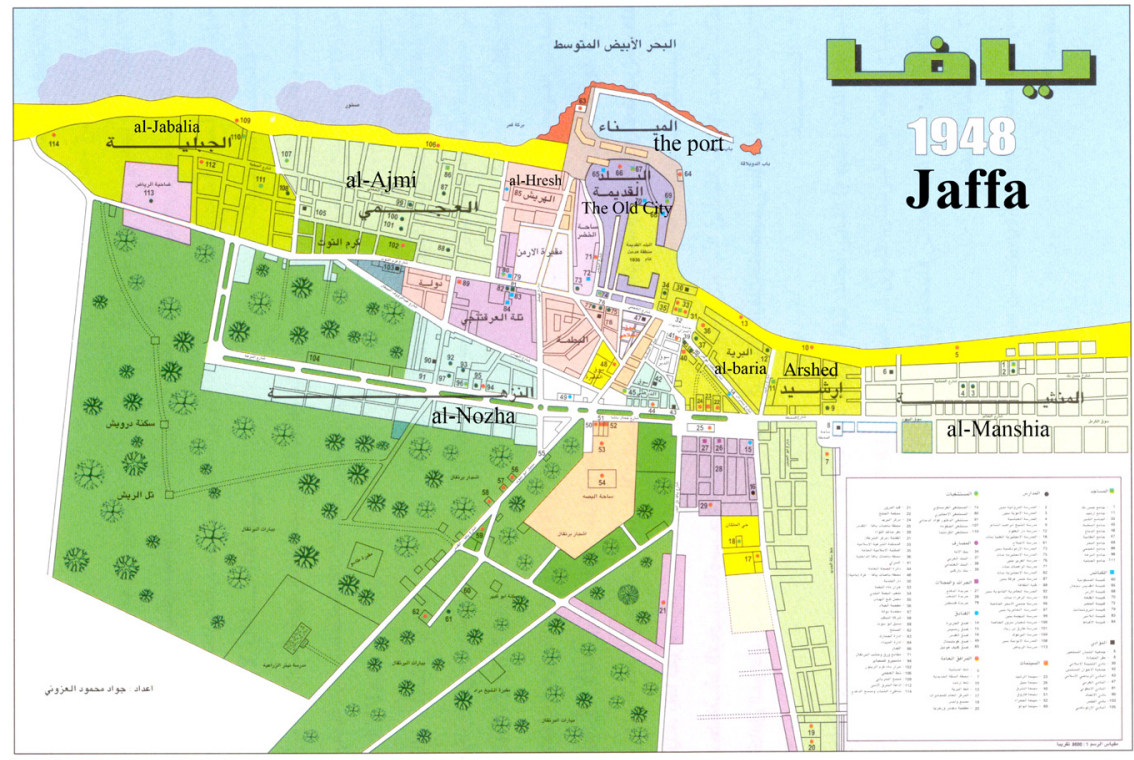

كافة خرائط الجولات استنبطت بتصرف من خارطة يافا ه\&A (السيد جواد العزوني)

Map 2. Jaffa before 1948.

Source: Prepared by Jawad Al-Azoni <http://ar.wikipedia.org/w/index.php?title=\%D9\%85\%D9\%84\%D9 \%81:Detailed_Map_Of_Jaffa_Before_Nakba.jpg\&filetimestamp=20111217223607>.

policies of control, judaization and exclusion of Palestinian inhabitants, with the support of the new-liberal economy through investment in infrastructure, by giving building permits, etc. (Hamdan-Saliba and Fenster, 2012; Goldhaber, 2010). As a result, new projects, exclusive housing projects in particular, appear in the heart of Jaffa, which are devised for the rich only and not for the Jaffa community.

Fourth phase: It represents the globalization of Jaffa, started in the last decade. Housing projects continue to be built in Jaffa spaces that are targeted not just at rich buyers from Israel, but also at international rich persons. These new residents live in isolated areas with regard to the Palestinian areas in Jaffa. In parallel, the municipality through "Israel Land Administration" and "Amidar" continues to sale the absentees' property and at the same time to submit "eviction orders", in total against approximately 500 Palestinian families living in Jaffa.

Finally, compared to Jaffa, Tel-Aviv was designed differently and built separately. It is a colonial city, based on the modern and development discourse, and was designed as a European and westernized city, which in effect destroys and changes the spatial and cultural appearance of Jaffa (Rothbard, 2005; LeVine, 1999). The destruction of Jaffa is not just physical but also includes destruction of the imagination, society, culture and history; for example, changing the old Arab names of streets and neighbourhoods. The construction of 
Tel-Aviv includes the process of preservation which differs to the process of destruction in Jaffa; however, both processes are viewed as methods of control (Hamdan-Saliba and Fenster, 2012; Rothbard, 2005).

In sum, the planning history of Jaffa, since 1948, reflects discrimination and unjust spatial planning policies, which work strongly to control and delete the Palestinian landscape, space and history. Accordingly, the coming section will discuss and present how these policies affect the everyday spatial practices of Palestinian women living in Jaffa, both as women and as belonging to the marginal and oppressed native group. Our discussion will be based on their narratives.

\section{Conceptual framework: Exclusion, alienation and belonging from/to different spaces as result of oppressive spatial planning policies}

This section focuses on the everyday spatial experiences of Palestinian women living in Jaffa Tel-Aviv. ${ }^{4}$ Specifically, it aims to examine the ways that planning policies and practices affect everyday spatial practices of Palestinian women (Muslims and Christian) living in Jaffa. To do this, the study adopted a qualitative method. In-depth interviews ${ }^{5}$ were conducted with sixty Palestinian women. Most of them belong to local families that were living in Jaffa before 1948. All the interviews were recorded and transcribed in Arabic, mother tongue both of the interviewees and mine. The women of the sample chose the place and the time of the interviews, normally at their homes or elsewhere in Jaffa. These women have different levels of education and belong to three age groups (young 14-40, middle-aged 40-65, and old 65+ years old).

Afterward, "thematic analysis" method was used to analyze the narratives, with the aim of identifying the main topics that recur within them (Ezzy, 2002; Rossmant and Fallis, 1998) and which are related to the article object, that is, the spatial planning policies and its impact on the everyday spatial experiences and practices of Palestinian women. The analysis of the links between the themes identified in the study led to the development of three concepts: a) spatial exclusion resulting of ignoring planning policies, b) feeling of alienation as a result of development and renewal and c) belonging to Jaffa due to the injust spatial planning policies. Each concept is abstract and made up of several themes, all of which are inter-connected. Each concept will discuss the national and the gender power relations, but not always in systematic way, due to their complexity and their dynamics.

These concepts will lead to develop a conceptual framework in order to interpret the results and to provide a comprehensive understanding regarding the study aims (Jabareen, 2009; Boyatzis, 1998).

4. This text stems from my $\mathrm{PhD}$ research, which was done at Tel-Aviv University, being Prof. Tovi Fenster my supervisor. From the same research is another article coauthored with Fenster (Hamdan-Saliba, Fenster, 2012), which focuses on tactics and strategies of power and the construction of spaces of belonging.

5. The interviews were conducted in summer and fall 2006. 


\section{Spatial exclusion as result of ignoring planning policies}

The widespread expression between the Palestinian women, when they were asked about their social and culture time, was "nowhere to go". Jaffa space, as similar to Palestine space, is result of national power relations, where the dominant group, the Jewish, wishes to control and Judaize it since 1948 (HamdanSaliba and Fenster, 2012; Yiftachel, 1998). In their narratives, the Palestinian women referred to the limited and narrow social and culture activities. The lack of services is less noticeable among younger women, due to their ability and desire to find other alternatives that can be far from home. Accordingly, Salam's (67 years old) desire for culture life is not reflected in the urban space of Jaffa, due to the lack of services and activities that could fit her needs and desires. This lack of services, actually distinguishes the everyday life of Palestinian women from Jewish women.

Before I participated in all activities and cultural shows, but now there is nothing can fit me. It can be that there are activities for young women. There is club for elderly people but I don't go, I don't feel good there. I wish that we have a cultural club to participate in it. Once I was in Holon [a Jewish city] and I saw women in my age in their way to the club, I felt jealous, because they have everything. The Palestinian women don't have anything, they are depressed. (Salam, 67 years old)

Accordingly, ignoring and discriminatory planning policies, which did not take into consideration the cultural differences of Palestinian women, have produced space of services that are not suitable for the Palestinian cultural lifestyle, and for women everyday needs. These practices thus lead to increasing exclusion into more limited space, restricting their accessibility to the public space, and increasing their feeling of non belonging. The national planning policies reflected also in neglecting policies, which has lead, in the last decades, to increasing incidents of murder and crime in the city (Monterescu, 2007; LeVine, 1999). This situation, in addition to the absence of gender sensitivity of planning and municipal bodies, raised the concerns of Palestinians women from free movement in the urban space. Lena (27 old), working woman, described her feeling of fear and its impact on her ability to move and behave freely in the urban space, in the following words:

I do not feel confident in my neighbourhood. I can't, for example, walk alone in the neighbourhood after 9:00 at night. There are drug addicts in the streets, there are thieves. So I am afraid to walk around at night

According to Lena narrative, her sense of belonging to the public spaces was harmed due to the threat of criminal acts, and due to the lack of consideration of local planning institutional for her needs, as a woman, of safety space. This sense of fear is common for Palestinians women regardless of age, education or social status. The outcome is a reduction in the geographical space of the 
women, by avoiding using at all some of those spaces, or a change in behaviour, such as not using the space late at night. The above narratives actually show the complexity of national and gender power relations in relation to the women spatial practices.

To deal with this discriminatory and inequitable space, women created their own alternative/Palestinian space that could accommodate and expand their spatial practices, and re-define their identity. This alternative/Palestinian space is reflected, firstly in the local initiatives activities, such as "Al-Saraya" and "Al-Rabita, the League for the Arabs of Jaffa" that seek to promote social and cultural life of the Palestinian population. Secondly, this alternative space is found in distant places. For example, by making trips to Palestinian cities such as Nazareth in northern Israel, or to cities located in the occupied territories, such as Ramallah. These spaces fit their cultural needs and increase their sense of belonging. Thus, they feel in comfort there. Najla (51 years old), working woman with low level of education, in her narrative referred to one of the local initiatives in which she participates, and she emphasizes her need to be away from home, to be part of the society and by that to strength her status as a woman. I quote her:

Recently I participated in a "computer course", conducted by a local women's association. It was different, but it was good and we were very happy ... There are many women who want to be part of this ... to be outside home is a different world, I like to be part of the social life.

Women's associations create new physical spaces, as that to which Najla refers, for instance simply in order to offer courses for women, but expanding in the process the public space accessible to women and strengthening their identity (Straigakos, 2002). These spaces also reflect the need and desire of women for something different that meet their demands, which the local planning and management of the city do not take into consideration and do not fulfil.

In sum, the denial and non-consideration of women needs by the planning and city management, due to being women who belong to Palestinian nationality, increased their spatial exclusion that already exist as a result of either gender or culture power relations.

\section{Feeling of alienation as result of development and renewal}

This concept reflects the alienation feeling and exclusion of Palestinian women from Tel-Aviv space, and from some spaces in the heart of their city Jaffa. These alienation and exclusion is caused mainly by globalization process, which is supported and carried out, partially, by the local planning institutions.

6. It is a non-profit organization that was established on 1979. The main purpose of the League is to preserve the Arab presence in Jaffa and to protect the rights of the Palestinians in Jaffa as an Arab Palestinian Minority. 
Global city can be a place of wealth on the one hand, or a place of deprivation and exclusion on the other hand, that already was there but has become clearer in terms of marginal groups (Eade, 2000; Marcuse and Kempan, 2000). This argument is reflected in the narratives of Palestinian women, for whom the global changes that occur in Tel Aviv increase their sense of strangeness and alienation in the city and thus increases their exclusion from this space. Not just the urban design and infrastructure changes create this alienation, but also the global economic development that has undergone in Tel Aviv. Accordingly, the globalization processes create spaces for specialized and professional people, and aside they create spaces and options for cheap jobs, occupied by minorities and marginalized groups (Marcuse and Kempan, 2000). Nadia (30 years old), working woman with high school level education, refer in her narrative to these economic changes:

There are new workplaces in Tel Aviv in high-tech, but that work isn't for us, not for the people of Jaffa. We aren't part of these changes. If you, as a Palestinian woman, apply to work there they wouldn't accept you.

Nadia emphasizes that these economic changes are in favour of the Jewish majority and not of the Palestinians people of Jaffa. At the same time, the women emphasize that the jobs which are offered for Palestinian, mainly for Palestinian women, are marginal and non professional jobs, as Najla (51 years old) argue:

There are no many Palestinians working in Tel-Aviv; it's just workplace for Jews. Palestinians are working in jobs such as construction; high-tech is only for Jews ... I know [Palestinian] women who work in hotels in Tel Aviv. There are women working in the shopping centres as retailers, and other works as clerks.

According to these narratives, those changes just increase and strengthen the employment and spatial discrimination and inequality between Tel Aviv and Jaffa. The above two narratives (of women who belong to different agegroup) emphasize how problematic are these changes and the complexity of power relations in relation to Palestinian women. They work in marginal jobs (according for Najla narrative) and, when they apply for some jobs, they are not accepted for being women and for belonging to the Palestinian nationality (according to Nadia narrative).

In fact, we can consider the globalization process as a spatial and planning tool, which reflects and implements the interests of the dominant group and, at the same time, ignores the Palestinian people in general, and the Palestinian women situations and needs, in particular. This process ends to exclude them from the new employment spaces, not just maintaining the socio-economic gap between the dominant, Jewish, and the marginal group, Palestinian, as Yiftachel (1998) argued, but rather increasing it.

As we have mentioned before, the last decade has seen the globalization process affecting the Jaffa space too. In recent years, under the name of deve- 
lopment and renewal, changes were made in the built environment of Jaffa.. Local planning and management initiated infrastructure developments and rehabilitation works, encouraging the entry of the private sector and external investments in the space of Jaffa. These processes caused demographic and spatial changes in Jaffa. Housing projects have been marketed and sold to international and Israeli rich Jewish people, luxurious residential complexes for Jewish people with financial capacity have appeared. These changes are clearly visible for Palestinians women. Nabila, 28 years old, in the next narrative refers to the processes of development and new construction taking place in Jaffa in the recent years and believes that this process is designed to Judaize Jaffa space:

Jaffa is changing; new buildings appear where wealthy people live in, mostly Jews out of Israel. We can't afford such apartments, it is much expensive for Palestinian living in Jaffa, we aren't part of that process ... This is plan, like to quick out the Palestinian from here, they want to Judaize Jaffa.

Palestinians women are aware that the development and renewal of Jaffa are intended for the "Other", the Jewish, and not for the Palestinians in Jaffa and that the purpose of these activities is a controlled space and Judaization. Sara, (54 years old) working and educated woman, refers to this transformation of Jaffa, as following:

It is true that now is much cleaner, there are fewer places neglected. But before I felt that is "Al-ajme" that it's ours and it's our home. Now we notes that they [the municipality] are cleaning, but not for us. This is for other people who are supposed to come and live here. It's depressing, that they are improving and cleaning to bring new people here, it makes me feel non-belonging ... There are people walking around here and asking: you don't know about building/ houses for sale? There are not from Jaffa or Tel Aviv, I even saw French people walking around here ... as an educator I teach my students to belong to Jaffa. When we love and feel belonging to place, we can preserve Jaffa, our home.

The development process described here, it is another tool to Judaizate Jaffa space, which caused exclusion of Palestinian from the planning discourse and practice, and which caused the feeling of alienation and non-belonging to the new spaces that were created in the heart of Jaffa. At the same time, contradictorily, it increases the sense of belonging to Jaffa itself (as it is clear in the following concept), as Sara indicate regarding the need of feeling of belonging to Jaffa and to preserve it as a Palestinian city. Of course, these global changes are real and have affected men as well. But we assume that women have been the most affected, due to their multiple roles, as working women, as mothers and as wives, which enforce them to use and know more in depth the immediate space, the neighbourhood space.

Sara, in her narrative, also refers to the process of globalization taking place in Jaffa as a result of rehabilitation, new development and entry of private market to Jaffa. These processes not only attract wealthy Jews from Israel, 
but also from abroad. Far from benefiting the local population of Jaffa, new separate spaces have been created bolstering the current Palestinian ghetto (Hamdan-Saliba and Fenster, 2012; LeVine, 1999). The Judaization of Jaffa's space through this development and globalization process, aims to conceal the memories of local residents, the Palestinians of Jaffa, by creating other space and other story. This type of evolution has been labelled by Sandercock (2003) "Memory theft", at it is reflected in Nadia (30 year old) narrative, when she is describing these spatial changes in Jaffa as "stealing" her memories of Jaffa buildings and streets. This "stealing" was done under the name of planning and development in order to implement the Zionist ideology (Fenster, 2007). Actually, by means of this "stealing", the local planning institutions are violating the women right to belong to and to use the urban space of Jaffa.

\section{Belonging to Jaffa due to the injustices of spatial planning policies}

This concept suggest, from the perspective of Palestinian women, that Jaffa is their city, here they belong and therefore prefer to use it, while Tel Aviv is a different city for them, where they have feeling of alienation, despite the higher level of development of the second city. Although, some of them use this space, mainly the young women, as free space, far away from the limitation and social pressure.

Jaffa symbolizes an individual and collective Palestinian identity for these women, which has the same language, belongs to the same nationality and culture, and has the same historical, cultural and spatial memories. Actually these elements emphasize the women feeling of belonging to Jaffa in response to the injustices planning and spatial policies have created. They have resulted in two separate spaces. On the one hand, a modern space, designed, well maintained and western. On the other hand, the other space, the Palestinian space has been destroyed and neglected. Sara (54 year old), working and educated woman, recognizes and emphasizes the spatial separation and difference between the Palestinian and neglected city, Jaffa and the Jewish, developed and cultivated city, Tel Aviv, in the following words:

Jaffa is my city ... I always says "I live in Jaffa"... Jaffa is not part of Tel Aviv ... I know that the Tel Aviv Municipality pays more attention to Tel Aviv. I see the differences when I travel to Tel Aviv. [Tel Aviv] is noisy, more lively and full of businesses, while Jaffa is abandoned and neglected.

The discriminatory planning and management policies that ignored the spatial history and collective memory of Palestinians native in Jaffa increased the spatial separation and distinction between Jaffa and Tel Aviv. This process caused to highlight the uniqueness of Jaffa as Palestinians' city, to which they belong, that they know and that includes private and collective memory of the native Palestinian nation. Natali (25 years old) compares the level of her familiarity of Tel Aviv, where she doesn't know many places and doesn't 
"know anyone", with Jaffa, her familiar space, and her daily living space. This familiarity construct her memory and this memory shapes and strengths her feeling of belonging to Jaffa spaces. According to de Certeau (1984), the repetitive everyday use of specific space creates the senses of belonging to the same space. Natali says:

I know everything in Jaffa; I know who owns this shop, I know the place, where to go. In Tel Aviv I don't know everything and don't know anyone. In Jaffa my family, it's my everyday life; Jaffa has everything, the store that I buy from it every day.

Familiarity and memory determine the feeling of belonging for a specific space, as a result of using this space frequently (Sandercock, 2003; de Certeau, 1984). Memory is part of the personal and collective identity which place the individual within a broad historical, national and culture context. Everyday spatial practice of individuals and groups is considered as a struggle for their right of belonging and memory, as well as a struggle for citizenship (Fenster, 2007; Sandercock, 2003). Accordingly, Badera (42 years old) feels uncomfortable and as a strange in Tel-Aviv, and due to injustice planning policies and practices, prefers to use the space of Jaffa:

I say that even if I'm free in Tel Aviv, I don't feel comfortable. ... Jaffa is my city, I have lived in it longer, it is where I move around more, it is where I speak my language and it houses all the buildings that I know and love. It is where I feel I belong.

According to de Certeau (1994), through our mobility through the city, walking the streets and paths, we increase our familiarity of the territory and give it meaning. Accordingly, for Badera, Jaffa is where she lives and moves; she knows the buildings and she loves it. Knowing and using these spaces strengthen Natali and Badera's feeling of belonging and comfort in Jaffa spaces, and they are also tools of struggle against the national power for belonging and memory. But at the same time, they are limited to their space and excluded from Tel-Aviv space.

In sum, Jaffa, as a space, creates a common experience for these women and therefore helps to create and consolidate their identity. We can consider women use, or increasing use, of Jaffa space as a resistance to the national power relationships. We assume these processes are affecting Palestinian women more than men, due their multiple roles and due to social and gender power relations, as we argue before.

\section{Conclusion: creating alternative spaces}

The dialectical relationship between Jaffa and Tel Aviv reflects the values and interests of the dominant group, the Jewish group. The planning system policies fail to meet or directly ignore the needs of Palestinians in the city. The 
result of Jaffa space planning, design and organization is to set strict limits to the spatial practices of Palestinians and to ensure the social, political and spatial exclusion of the Palestinians. These limitations and exclusions are more radical and clearer in the case of Palestinian women than in the case of men, due to their different needs and culture experience.

The ignoring, neglecting and discriminatory planning and city management policies and practices, which have not taken into consideration the historical, cultural and gender differences and needs of the Palestinian women in Jaffa, has produced un-appropriate and un-safety spaces. According to the Palestinian women living in Jaffa, both the un-appropriate space which doesn't include suitable culture and social services, mainly for older women, and the un-safety space as a result of the criminal activities in Jaffa space, have led to a changing and declining women geographical daily space, Women have been excluded to more limited spaces, their mobility and behaviour in the public spaces have been restricted. This un-appropriate space, actually distinguishes the everyday life of Palestinian women from Jewish women, who belong to the dominant group. The needs of the latter are more reflected in the urban space.

In addition, the urban renewal and global development, through economic, urban and infrastructure changes, increase women feeling of strangeness and alienation in Tel Aviv and in the gated spaces in Jaffa. We can consider these developments and global changes as spatial tools used by the city management that support the Zionist project of controlling the city and judaizing Jaffa. The Palestinian women are aware that the process of renewal that take place in Jaffa is not for the benefit of Palestinians in Jaffa, but rather to create a new spatial reality. This process conceals and deletes the history and the memory of the native people, and instead it creates a new Jewish spatial reality and memory.

Actually the above discussion highlights the complexity of everyday spatial experience of Palestinian women living in Jaffa. Their daily experience is affected not just for being women but also for being women who belong to a marginal and native group. Accordingly, and contradictorily, ignoring the urban spatial history of Jaffa and the memory of its native residents, has led Palestinian women to emphasize the Jaffa's space as a different and Palestinian space. This daily spatial context has references to the same culture, language and memory, and it is a known and familiar space for them. At the same time, these policies enforced Palestinian women to create alternative-Palestinian spaces, which although limited and narrow, are able to expand their spatial mobility, promote belonging feelings and re-define their identity. These spatial practices and the emphasis on the spatial memory of their nation and culture, are a way of resistance and struggle for their rights, for their cultural and spatial history and for their belonging. 


\section{Bibliographical references}

Al-Bawab, Ali Hassan (2003). Encyclopedia of Beautiful Yaffa. Amman: The Arab Institute for Studies and Publications. (Arabic).

Bishara, Azmi (2008). "The Search for Meaning for the Nakba”. Al-Quds, 26 May 2008, newspaper site <http://www.alquds.com/node/29253> (Arabic).

BOYATZIS, Richrd E. (1998). Transforming Qualitative Information. Thousand Oaks. London, New Delhi: Sage Publications.

Casey, Edward (1987). Remembering: A Phenomenological Study. Bloomington: Indiana University Press.

Cresswell, Tim (1996). Place/Out of Place: Geography, Ideology and Transgression. Minneapolis: University of Minnesota Press.

De Certeau, Michel (1984). The Practice of Everyday Life. Berkeley, Los Angeles, London: University of California Press.

EADE, John (2000). Placing London, From Imperial Capital to Global City. New York and Oxford: Berghahm Books.

EZZY, Douglas (2002). Qualitative analysis, practice and innovation. London: Routledge.

FEnster, Tovi (2005). "The Right to the Gendered City: Different Formations of Belonging in Everyday Life”. Journal of Gender Studies, 14 (3), 217-231.

- (2007). "Gender, religion, and urban management". In: Karen M. Morin and Jeanne Kay Guelke (eds.). Women, Religion, and Space, Global Perspectives on Gender and Faith. Syracuse university press, 41-60.

FINCHER, Ruth and JACOBS, Jane M. (1998). “Introduction”. In: Ruth Fincher and Jane M. Jacobs (eds.). Cities of Difference. New York London: the Guilford Press, 1-25.

Foucault, Michel (1980). Power/Knowledge. New York: Harvester Wheatsheaf.

Goldhaber, Ravit (2010). "The Jaffa Slope Project': An Analysis of 'Jaffaesque' Narratives in the New Millennium". Makan, Adalah's Journal for Land, Planning and Justice, 47-69.

Hamdan-Saliba, Hanaa and Fenster, Tovi (2012). "Tactics and strategies of power: the construction of spaces of belonging for Palestinian women in Jaffa-Tel Aviv". Women's Studies International Forum, 35, 203-213.

HarveY, David (1996). Justice, Nature and the Geography of Difference. Oxford: Blackwell publishers.

Hayden, Dolores (1995). The Power of Place: Urban Landscapes as Public History. Cambridge: the MIT Press.

Healley, Patsy; Cameron, Stuart; Davoudi, Simon; Graham, Stephen and MadaniPour, Ali (eds.) (1997). "Introduction: The City - Crisis, Change and Invention". Managing Cities, the New Urban Context. Chichester, New York, Brisbane, Toronto, Singapore: John Wiley and Sons, 1-20.

JABAREEN, Youseef (2009). "Building a conceptual framework: philosophy, definitions, and procedure". International Journal of Qualitative Methods, 8, 50-62.

JACOBS, Jane M. (1996). Edge of Empire, Postcolonialism and the City. London: Routledge.

KILD, Jeanne Halgren (1999). "The 'Predominance of the Feminine' at Chautauque: Rethinking the Gender-Space Relationship in Victorian American”. Sign, 24 (2), 449-486.

LEACH, N. (2002). "Belonging: towards a theory of identification with space". In: J. Hillier and E. Rooksby (eds.)._Habitus: A Sense of Place. Aldershot: Ashgate, 281-298. 
Lefebvre, Henri (1991). The Production of Space. Oxford: Blackwell.

LeVINE, Mark (1999). Overthrowing Geography, Re-Imagining Identities: A History of Jaffa and Tel Aviv, 1880 to the Present. Dissertation submitted in partial fulfillment of the requirements for the degree of Philosophy Department of Middle Eastern Studies. New York: New York University Press.

Madanipour, Ali (2003). "Social Exclusion and Space". In: Tichard T. Legates and Frederic Stout (eds.). The City Reader. London: Routledge.

MAKDISI, Jean Said (2005). "The Mythology of Modernity: Women and Democracy in Lebanon". In: Haideh Moghissi (eds.). Women and Islam, Critical Concepts in Sociology. London and New York: Routledge.

MARCuSE, Peter (1995). "Not Chaos, but walls: postmodernism and the partitioned city”. In: Watson S. and Gibson K. (eds.). Postmodern Cities and Spaces. Oxford: Blackwell.

Marcuse, Peter and Kempan, Ronald van (2000). "Introduction”. In: P. Marcuse and R. van Kempan (eds.). Globalizing Cities: A New Spatial Order? London and Cambridge: Blackwell Publisher.

Markus, Thomas A. (2002). "Is There a Built Form for Non-Patriarchal Utopias?". In: Bingamen, Amy; Sanders, Lise and Zorach, Rebecca (eds.). Embodied Utopias, Gender, Social Change and the Modern Metropolis. London: Routledge, 1-12.

Martin, Brenda and SPARKe, Penny (2003). "Introduction”. In: Brenda Martin and Penny Sparke (eds.). Women's Places: Architecture and Design 1860-1960. London and New York: Routledge.

Massey, Doreen (1994). Space, Place and Gender. UK: Polity Press.

MaZAWI, Andre and KhourY-Makhoul, Makram (1991). "Spatial Policy in Jaffa, 1948-1990". In: Luski, H. (eds.). City and Utopia: Compilation of Materias sTel Aviv-Jaffa celebrate their eightieth anniversary. Tel Aviv: Israeli Publishing Co., 62-74. (Hebrew).

Mitchell, Don (2000). Cultural Geography: A Critical Introduction. Oxford: Blackwell.

Monterescu, Daniel (2007). "Heteronomy: The cultural logic of urban space and sociality in Jaffa". In: Daniel Monterescu and Dan Robinowits (eds.). Mixed towns, trapped communities: historical narratives, spatial dynamics, gender relations and culture encounters, in Palestinian-Israeli towns. UK: Ashgate Publishing, 157-178.

RaZACK, Sherene H. (1998). Looking White People in the Eye, Gender, Race, Culture in Courtrooms and Classroom. Toronto Buffalo, London: University of Toronto Press Incorporated.

RITZDORF, Marsha (1997). "Locked out of paradise: contemporary exclusionary Zoning, the Supreme Court, and African Americans, 1970 to the present”. In: Thomas J.M. and Ritzdorf M. (eds.). Urban Planning and the African American Community in the Shadows. SAGE Publications, 43-57.

Rossmant, Gretchen B. and RaLlis, Sharon F. (1998). Learning in the field, an introduction to qualitative research. California: Sage.

ROTHBARD, Sharon (2005). White city, black city. Tel Aviv: Babel (Hebrew).

SAID, Edward W. (1999). "Palestine: Memory, Invention and Space". In: Ibrahim Abu-Lughod; Roger Jeacock and Khaled Nashef (eds.). The Landscape of Palestine: Equivocal Poetry. Birzeit: Birzeit University Publications.

SANDERCOCK, Leonie (2000). "When strangers become neighbors: managing cities of difference". Planning Theory and Practice, 1 (1), 13-20.

- (2003). Cosmopolis II Mongrel cities of the 21st century. London and New York: Continuum. 
Sibley, David (1995). Geographies of Exclusion - Society and Difference in the West. London and New York: Routledge.

SpaIN, Daphne (1993). Gendered Spaces. Chapell Hill and London: The University of North Carolina Press.

TAMARI, Salim (2000). "Treacherous Memories: Electronic Return to Jaffa". In <www. palestineremembered.com>.

WILSON, Elizabeth (1991). The Sphinx in the City. Berkeley: University of California Press.

- (1995). "The Invisible Flaneur". In: Watson Sophie and Gibson Katherine (eds.). Postmodern Cities and Spaces. Massachusetts: Blackwell Publishers.

YACOBI, Haim (2002). "From urban panopticism to spatial protest: housing policy, segregation and social exclusion of the Palestinian community in Lydda-Lod". Middle East Report, 223, <www.merip.org>.

YIFTACHEL, Oren (1998). "Planning and social control: Exploring the dark side". Journal of Planning Literature, 12, 395-406.

- (2006). Ethnocracy, Land and Identity Politics in Israel/Palestine. Philadelphia: Pennsylvania Press.

Young, Iris Marian (1990). Justice and the Political of Difference. Princeton, NJ: Princeton University.

ZuKIN, Sharon (1995). The Cultures of Cities. USA: Blackwell Publishers. 